\title{
Early Stages of Service Business - Review and Synthesis
}

\section{Matti Muhos*, Anna-Mari Simunaniemi and Martti Saarela}

Oulu Southern Institute, Micro-entrepreneurship research group

University of Oulu, Pajatie 5,

FI-85500 Nivala, Finland

E-mail: matti.muhos@oulu.fi

E-mail: martti.saarela@oulu.fi

E-mail: anna-mari.simunaniemi@oulu.fi

\section{Delbert Foit Jr. and Lada Rasochova}

Rady School of Management, University of California,

San Diego, CA, USA

Email: 1rasochova@ucsd.edu

Email:dfoit@ucsd.edu

*Corresponding author

\begin{abstract}
Many stage models have been introduced to clarify management priorities during the early stages of business growth. However, many of these models are conceptual and universal, providing only limited benefits to specific industries and business contexts. The early stages of technology-based ventures have attracted interest, while little attention has been paid to the early stages of service-based firms. This study examines the early stages of growth in servicebased firms. The following research questions are posed: What are the basic characteristics of recent empirical studies on the early stages of service-based firms? What are the themes and sequential patterns in the early stages of servicebased firms as revealed in the recent empirical literature? This study provides a meta-analytical review designed to answer the research questions. A group of recent empirical stage models of the early stages of service-based business was selected for meta-analysis and synthesis. The meta-analysis integrates the findings of these models and introduces a self-evaluation framework for the early stages of service-based companies.
\end{abstract}

Keywords: enterprise development; growth management; stages of growth; growth process; service-based firm; business development; meta-analysis; review.

Biographical notes: Dr. Matti Muhos is the Research Director of MicroEntrepreneurship at the University of Oulu. He has a title of docent in technology business at University of Jyväskylä. D.Sc. (Tech.) Muhos has received his doctorate in industrial engineering and management from Universtity of Oulu. He participates in the editorial processes of several international journals as an 
associate editor, quest editor and advisory board member. His primary research interests are the growth management in new technology and service based firms, the development of SMEs and micro-sized enterprises, technology business, technology management, agility, and internationalisation processes.

Martti Saarela is a researcher and $\mathrm{PhD}$ candidate at Oulu Southern Institute of University of Oulu. He holds a Master of Laws and Master of Science in Economics. His primary research interests are the development of microcompanies, public business services, external entrepreneur support, public procurement, and regional development. In recent years, he has been involved in many projects in the area of regional development.

Dr. Anna-Mari Simunaniemi is working as project researcher at the Microentrepreneurship research group MicroENTRE at the University of Oulu. Ph.D. Simunaniemi has received her doctorate in food, nutrition and dietetics from Uppsala University, Sweden. She is currently involved in research focused on early stages of growth in enterprises in social and health care sector. Simunaniemi has in recent years been involved in several regional development projects mainly in the fields of social and health care and food business. Her primary research interests are in the regional development and development of SMEs and micro-sized enterprises.

Dr. Lada Rasochova is the Executive Director of the California Institute for Innovation and Development (CIID) and the Managing Director of the Rady Venture Fund (RVF) at the Rady School of Management at the University of California, San Diego. She has extensive managerial experience in technology commercialization and innovation-driven enterprises and industries. Dr Rasochova received her $\mathrm{PhD}$ in molecular, cellular and developmental biology from Iowa State University and her MBA from the Rady School of Management at the University of California, San Diego.

Delbert Foit Jr. is a lecturer at University of California San Diego Rady School of Management. He has extensive industrial and entrepreneurial experience as a senior executive with 32 years of experience in operations management and nine years of academic experience. His industrial expertise is in pharmaceutical manufacturing, biotech manufacturing, medical diagnostic reagents and kit manufacturing, biotech and medical diagnostics product development, materials management, purchasing, planning and regulatory compliance. His academic expertise is in opportunity identification, business model and company creation.

\section{Acknowledgements}

The authors are grateful for the generous support of the Finnish Funding Agency for Innovation, the Council of Oulu Region and the Centre for Economic Development, Transport and the Environment, as well as and all other important partners and supporters of this research process in Finland. Moreover, the authors greatly appreciate the support provided by the University of California Rady School of Management (UCSD Rady). A significant part of this study was generated during a research visit to UCSD Rady. 


\section{Introduction}

Company growth can be studied from multiple perspectives. The literature in this area includes perspectives such as static equilibrium theories (e.g. Coase, 1937), stochastic models (e.g. Gibrat, 1931), transaction cost theories (e.g. Williamson, 1975), economics of growth theories (e.g. Penrose, 1959), resource-based theories (e.g. Penrose, 1959), evolutionary theories (e.g. Nelson \& Winter, 1982), organisational ecology theories (e.g. Hannan \& Freeman, 1977), strategic adaptation theories (e.g. Sandberg \& Hofer, 1982), motivational theories (e.g. McClelland, 1961) and configuration theories (e.g. Churchill \& Lewis, 1983; Greiner, 1972). This study focuses on the latter, which is the configuration perspective. Most other perspectives are concerned with the factors that lead to growth, whereas the configuration perspective deals with the actual growth process. According to Davidsson and Wiklund (2006), the configuration perspective focuses on how managerial problems occur and how they can be dealt with during the firm's presumed growth in typical stages of development. Wiklund (1998) pointed out that this perspective mainly concerns the benefits that growth brings to an organisation. When the firm's growth is considered the starting point or the cause, the consequences for the firm become the main concern. Previous studies on the quantitative determinants of growth did not yield much insight into the process itself. This study aims to clarify managerial priorities in the early stages of growth. It explores, describes and explains how growth affects a company and how a growing company can be managed (e.g. Davidsson \& Wiklund, 2006; Wiklund, 1998).

The configuration perspective is often called the 'stages of growth' or 'life-cycle' perspective (e.g. Muhos, Kess, Phusavat, \& Sanpanich, 2010). In the recent literature (e.g. Phelps, Adams, \& Bessant, 2007), other terms, including 'states of growth', have been proposed. Among the first authors to use 'configuration' in this sense are Miller and Friesen (1984), who agreed with Hanks, Watson, Jansen, \& Chandler (1993) that life-cycle stages are best characterized as configurations. According to this view, the key attributes (e.g. structures, systems and information procedures) tend to influence each other in a manner that gives rise to a small number of configurations that represent common developmental or transitional sequences. In these studies, the term stage corresponds to a unique configuration of the variables (e.g. strategies, problems and priorities) that growing firms are likely to face (see Miller \& Friesen, 1984).

The configuration perspective on enterprise growth has attracted the interest of both academic and the pragmatic audiences. Its obvious strengths are in describing the characteristics of the growth process: what changes and how? Moreover, the configuration perspective offers powerful explanations for the underlying causes of the process. However, the configuration perspective has been criticised as overly deterministic (e.g. Churchill \& Lewis, 1983; Dodge, Fullerton, \& Robbins, 1994; Geroski, 2002; Miller, 1981; O'Farrell \& Hitchens, 1988; Perry, 1982; Siu \& Kirby, 1998; Stubbart \& Smalley, 1999; Whetten, 1987), conceptual (e.g. Hanks \& Chandler, 1994), too general and simplistic (e.g. Tornatzky et al., 1983; Whetten, 1987).

The configuration models developed during the past few decades vary widely according to focus industry, the use of empirical evidence, the number of stages and other factors (e.g. Siu \& Kirby, 1998). Recent reviews of the literature have described several models (see Levie \& Lichtenstein, 2010; Muhos et al., 2010; Phelps et al., 2007). In the management literature, generic analyses of these models showed neither consensus nor empirical confirmation of the stages theory because many of such models and frameworks are conceptually based. However, focused empirical models have produced consistent 
findings. Empirical studies have traditionally focused on technology-based firms. Empirical tests by Hanks et al. (1993) and Kazanjian \& Drazin (1990), among others, have provided support for the applicability of the models focused on technology-based firm. Moreover, the results of tests of the tech-focused empirical stage framework supported the applicability of this framework to the business contexts of four countries (Muhos, Kess, Rasochova, \& Foit, 2016; Muhos, Lee, Chang, \& Kess, 2014; Muhos, Kess, Distanont, Phusavat, \& Sanpanich, 2014).

Empirical models of the early stages of service-based firms are rarer in the literature. However, in recent studies, models have focused on service-based firms, some of which empirically based. Hence, there is a need to synthesise the findings of empirically based models, which would allow the integration of their main findings Moreover, the review and synthesis of models of service-based businesses could reveal patterns, trends and potential blind spots as well as open potential paths for the further development of these models. Therefore, the following research questions are posed: 1) What are the basic characteristics of recent empirical studies on the early stages of service-based firms? 2) What are the themes and sequential patterns in the early stages of service-based firms as revealed in the recent empirical literature?

The aim of this study is to fill the above-described gap in the research by analysing selected configuration studies on service-based businesses. First, this study provides a review of selected attributes in configuration models of the growth of service-based businesses. Second, by conducting an explorative in-depth meta-analysis of the most recent empirical models, this study seeks to integrate some of the main common themes and sequential patterns presented in these models.

\section{Method}

This study conducts a meta-analysis of previous studies in order to integrate some of their findings. The meta-analysis is especially useful when the literature contains a large number of studies that deal with the same area of interest (Glass, 1976). This is the case with studies of growth configuration. Because this is a meta-analytical study, it does not include preliminary or secondary data. According to Cook et al. (1992), all studies combine evidence found in units of analysis. In a meta-analysis, these units are published reports.

This meta-analysis focuses on growth configuration studies of the early stages of service-based businesses. The key phases of the research process utilised this study are based on Cook et al. (1992) and Cooper, Hedges, and Valentine (2009). According to Cooper et al. (2009), the key phases of the meta-analytical research process are as follows: 1) problem formulation, 2) literature search, 3) data evaluation, 4) data analysis, 5) interpretation of the results and 6) public presentation. In the present study, the research process follows these phases, which are illustrated in Figure 1:

[Figure 1 should be placed here]

First, in the design phase, preliminary understanding was generated through the literature review and the in-depth analysis of earlier extensive reviews of models of the stages of growth (see Levie \& Lichtenstein, 2010; Muhos et al., 2010; Phelps et al., 2007). These meta-analyses provided a wide perspective on the broad configurations literature. After generating a preliminary understanding, the problem was defined and the research was planned, which resulted in the research design of the meta-analysis. Second, in the data collection phase, two rounds of a literature search and data evaluation were carried 
out, which resulted in the selection of the final data set. Third, the selected data were analysed following the above-described logic of meta-analysis and data interpretation was conducted. Fourth, the results were described, as well as their implications for academics and practitioners who are interested in the early stages of service-based firms.

The sample of empirical configuration studies on the early stages of service-based firms was collected and analysed in 2014 at University of Oulu, Finland. The analysis of the sample was carried out during the fourth quarter of 2014 at the University of California San Diego (UCSD) in the Rady School of Management. Conclusions based on the main findings were drawn in 2015. This study addresses both academic and pragmatic audiences interested in the process perspective on company growth and development.

\section{Early stages of service-based companies: Data collection}

Studies published in 1980 or later were included in the preliminary sample to ensure sufficient accessibility. Two periods, 1980 to 1999 and 2000 to 2014 were established to explore potential shifts or changes in the characteristics of these studies. The preliminary sample of models selected for this meta-analysis included configuration models that met the following criteria: 1) published within the period of 1980 to 2014; 2) based on empirical evidence; 3 ) focused on service businesses. In the preliminary sample, both models were focused on service businesses. Generic models added value to service business growth. Twenty-five studies meeting the above criteria were included in the preliminary sample. The selection included peer-reviewed international journal articles, conference articles and books published by well-established academic publishers.

The analysis of the preliminary sample covered the identity of the models (author(s)' identity, publication's identity and year published), basic descriptive attributes (number of stages and focus on the business sector(s) of the model) and attributes related to the methodology and underlying assumptions (peer reviewed or not, research strategy and size of the sample). These characteristics are presented in Table 1.

[Table 1 should be placed here]

In the preliminary selection, a minority (11 studies) were published during the 1980s and 1990s. The majority (14) of the studies were published in or after 2000. A moderate increase in the number of studies occurred after 2000. As shown in Table 1, the majority of models published in the 1980s and 1990s can be characterised as generic models that added limited value to the service-based context. In fact, only one of the early models focused on service-based businesses. However, among the models published in or after 2000 , the number of studies on service businesses increased dramatically. This increase seems to be part of the increasing interest in focused studies.

The number of proposed stages varied widely across the sample. The two periods of analysis and the number of stages proposed by the authors of the models are presented in Figure 2:

[Figure 1 should be placed here]

The number of stages varied widely according to the 'focal length' of the models. Some models focused only on the very beginning of growth, while others took a wider approach. The number of stages varied less among recent studies published in and after 2000. The number of stages proposed by generic models varied (between 2 and 6 stages) more than 
the service business-focused models ( 3 to 5 stages). However, even more important than the number of stages is the content of the stages proposed. The preliminary content analysis showed remarkable consistency among the service-focused models. In fact, the service business-focused models seemed more consistent than the generic models did.

The research strategies of these studies included case studies, surveys and action research. Case studies and surveys were the most popular approaches. Case studies were the most popular approach during the 1980s and 1990s. Among the recent studies, the number of surveys increased dramatically, which indicates that this method has been the most popular since 2000 .

The size of the empirical sample, that is, the number of cases, varied greatly according to the selected research strategy. No trends were revealed when the two periods were compared. The largest sample came from the survey of a sample of 2,903 companies. On the other end of the spectrum were two in-depth single case studies and a longitudinal action research study of a single organisation.

Based on the review of preliminary sample, the following conclusions were drawn: 1) among recent models, the number of studies on service businesses had increased dramatically; (2) most empirically based surveys were conducted in recent studies; 3 ) recent studies used stages that were more consistent than in early studies; (4) the studies clearly focused on service businesses showed remarkable consistency compared to the generic models regarding both the number of stages and their content. Based on the review of preliminary sample, recent models with a clear focus on service-based businesses were selected as the final sample used for the in-depth meta-analysis.

\section{Early stages of service-based companies: Data analysis}

Nine recent empirical configuration models of the early stages of service-based firms were selected for the explorative meta-analysis presented in this study. The purpose of this metaanalysis is to describe the characteristics of these models in order to lay a foundation for the development of reliable frameworks for self-evaluation and further analysis of the early stages of service-based businesses. The models selected and further analysed are presented in Table 2.

[Table 2 should be placed here]

First, Shim et al. (2000) presented a five-stage, four-transition model of an organisational lifecycle approach to the examination of US Hispanic-owned small retail and service businesses. The key areas analysed in this study were management decisionmaking style, complexity of structure, operational systems, strategic planning and owner involvement. The stages were existence, survival, success, take-off and resource maturity.

Second, Greiner and Malernee (2005) presented a four-stage, four-crisis model of managing growth stages in professional service firms, particularly consulting. The data were collected from US-based professional service firms. The main perspectives analysed in this study were strategy, organisational structure, systems and rewards, management style, decision process, culture and sources of conflict. The stages were; exploring the market for growth opportunities, focusing on specialised market niche, diversifying into multiple offices and related services and institutionalizing into a one-firm firm.

Third, Masurel and Van Montfort (2006) presented a four-stage model of the lifecycle characteristics of small professional service firms. The data were collected from Dutch 
architectural firms. The key factors analysed in the study were sales diversification, labour force differentiation and labour productivity. The stages tested in the study were starting phase, growth phase, maturity phase and decline phase. The results confirmed the increasing patterns of sales diversification, labour force differentiation and labour productivity through three developmental stages, as well as the decreasing patterns in the declining companies.

Fourth, Teeter and Whelan-Berry (2008) presented a four-stage model of the challenge of change in growing a small professional service firm. The key perspective analysed in this study was organisational change management. This was an in-depth single case study of a US accounting firm. The stages presented in this study were start stage, growth stage, mature stage and decline stage. This study concluded that the transitions between lifecycle stages could be managed more effectively when they were viewed as organisational cultural changes.

Fifth, Auzair (2010) presented a three-stage model of stages in the organisation's life cycle and management control systems in service organisations. The data used in this survey were collected from diverse service industries operating in Australia, including retail and wholesale, health services, education, hospitality, transportation, finance, insurance and professional services. The key perspective analysed in this study was management control systems. The stages presented in this study were formation, growth and maturity.

Sixth, Van Tonder and McMullan (2010) presented a five-stage model of franchise growth. The data were collected in South African franchisees. The key perspective of the study was growth-related organisational change. The stages described and preliminarily tested in this study were gestation, entrepreneurial, methods and systems, and maturation decline and renewal.

Seventh, Witmeur and Fayolle (2011) developed and tested a four-stage typology of growth strategies in entrepreneurial IT service firms. The typology was tested through four case studies of IT service firms in Belgium. The key perspectives of this study included entrepreneurial team, activities, resources, organisational structure, business environment and growth strategy. Two typologies were proposed and studied. The first consisted of start-up, early growth and continued growth. The second consisted of seed, start-up, early growth and continued growth. The first focused on the characteristics of a traditional IT service firm, whereas the second focused on the characteristics of the 'software lab' type of IT service firm.

Eighth, Ferreira et al. (2011) presented a five-stage taxonomy of service business growth by combining life cycle and resource-based theories. The data were collected from the hotel and restaurant service industries of Cape Verde. The key perspectives analysed were context, structure, strategy, decision-making style and level of resources. The lifecycle stages were birth, expansion, maturity, diversification and decline.

Ninth, Empson (2012) presented a five-stage, five-crisis model focused on governance in professional service firms. The model was based on historical narratives collected through 13 in-depth case studies of companies, including management consulting firms, law firms, accounting firms and actuarial firms in Great Britain. The key perspective of this study was governance changes over time. The stages of founder focused, collegial, committee, delegated and corporate were used in this study.

The comparison of the key characteristics of the models analysed is presented in Table 3.

[Table 3 should be placed here] 


\section{Identification of the shared themes and the shared sequences}

To delineate the findings of these models, the main common themes were determined through an in-depth meta-analysis. The shared perspectives then were classified into the following nine themes:

1. Focus

2. Power

3. Organisational structure

4. Decision-making systems

5. Strategic management

6. Development and delivery of services

7. Marketing

8. Human resources

9. Growth

Second, the meta-analysis delineated the findings of the models based on the nine perspectives. Each theme, or category, was used to delineate the similarities of each model as it related to the particular theme. The models were found to be consistent in content and the sequential order of the challenges and activities related to each theme. The number of sequences varied from model to model based on the various decisions of the authors, including the focus of the analysis. Some of the models focused on early stages, while others were general. In some models, the first stage was divided into two distinctive stages and others used only one stage. The delineation results are presented in the Table 4:

[Table 4 should be placed here]

The three models that proposed "decline" as a separate stage are typical deterministic life-cycle models that assumed that the decline stage was part of a natural growth cycle that was comparable to the other developmental sequences. In the probabilistic stages of growth or the states of growth models, there was no need for a separate the decline stage because the potential for decline and "death" was present in every stage of growth and development.

\section{Results}

The next logical step in this meta-analysis was to generate a detailed synthesis using the above-described sequences and the classification scheme. The synthesis was condensed using the nine themes presented in this study. Moreover, based on the in-depth analysis of the content of the sequences presented by these nine models, the four sequences were established as a baseline for the synthetic framework. Condensed versions of the four sequences related to each of the nine themes are described in the following paragraphs.

Focus. Under this theme, the models described the changes in the company's focus during the early growth sequences of a service business. The models were agreed that during the first sequence, the focus of new and fragile service businesses was on the development and delivery of services and building market identity in order to survive. Second, in expanding service-based firms, the focus shifted to growth management as market acceptance led to rapid growth and constant change. Third, as market becomes saturated, the focus of the service-based firm gradually turned to the improvement of 
efficiency by formalising rules, procedures and financial controls. In the fourth sequence, according to the meta-analysis, the growing service-based business focused on new service generations, business areas and/or locations and on building a uniform business culture.

Power. This theme focused on who uses the power in growing service business and how it is used. The models agreed that during the first sequence of service business growth, the power was owner-centric. Decision-making was owner-dependent because the ownermanager or team of owner-managers led only a small group of employees. During the second sequence, owner-manager(s) maintained control but began to delegate responsibilities to a small management team as the company experienced increasing growth. In the third sequence, in organisations focused on efficiency, rules, procedures and control, professional executives were called to support the original owner-manager and the management team. Finally, during the fourth sequence, the original owner-manager or management team was supported or replaced by professional leaders with corporate experience. External support was needed in the diversifying organisation to create a uniform culture and to manage the growing portfolio of new service generations, business areas, and locations.

Structure. The term structure here refers to how the organisational structure changes during the early stages of service business growth. During the very first sequence, the structure is simple, informal and owner-centred because the company is focused on the development of service and market identity. As the company moves through market acceptance to the second sequence, which is characterised by growth and change, the structure is formalised through unavoidable task specialization. In the third sequence, which is characterised by market saturation, a formal structure with defined roles and responsibilities is introduced. Finally, in the fourth sequence, a sophisticated structure with formalised functions and processes is introduced as the company builds new growth momentum through new services, locations and business areas.

Decision-making systems. This theme refers to the development of IT-based decision support systems in growing service-based firms. The models were agreed that during the first sequence, which is focused on service and market identity development, formal decision-making systems and procedures are almost non-existent. Through market acceptance at the beginning of the second sequence, the firm moves rapidly from basic decision-making systems to scalable systems that are compatible with the growing business. In the third sequence, in a saturated and highly competitive market, the service business seeks to maintain its market share and profitability through written strategies and rules and by policies supported by comprehensive operational systems. In the fourth sequence, codified strategies, rules and policies are communicated by sophisticated analytical mechanisms and systems that support 'the company approach'. In other words, a uniform business culture is built. Moreover, an increasing number of new services, locations and business areas require sophisticated decision-making systems.

Strategic management. This theme refers to the changing characteristics of long-term planning, patterns and/or ploy as the service business grows. According to the models, during the first sequence, owner-managers do not have time for strategic planning because the focus is on the hands-on development of services and market identity. In the second sequence, as the company faces market acceptance and rapid growth, strategic planning is focused on maintaining continuous growth. According to the models, as the company reaches resource maturity in the third sequence, strategic management becomes both formalised and supported by financial resources. Based on the models, in the fourth growth sequence, strategy implementation is already a routine activity in the corporate headquarters of a service-based organisation. 
Service development and delivery. This theme refers to how services are developed and delivered during the early growth of service-based firms. The analysis of the models showed that the development and delivery of innovative services are the primary focus and therefore part of everyone's job in a newly established service-based business. As the company moves forward to the next sequence through market acceptance, the focus moves from development to efficient delivery and scaling of the services. According to the models, as the resource-mature company faces saturated market conditions in the third growth sequence, fresh and continuous innovation methods are implemented to avoid stagnation. Finally, in the fourth sequence, innovative culture enables the implementation of diversified service-market strategies, and the momentum of creative growth returns.

Marketing. This theme refers to the changes related to the sales and marketing activities of a growing service business. The meta-analysis showed that in the first sequence, the marketing activities in a new service business are focused on attracting early customers. As the company reaches market acceptance and growth in the second sequence, the sectors, activities and client types at the focal point of marketing activities increase rapidly, as does the workload of marketing. As the company reaches resource maturity in a saturating market, in the third sequence, new ideas are required in marketing to maintain market position, expand and/or renew. Finally, in the fourth sequence, as growth momentum is regained through diverse growth strategies and a high-level growth culture, a uniform image is spread to diverse markets through sophisticated marketing.

Human resources. This theme refers to how the characteristics of human resource management change as the service business proceeds through the early growth process. According to the models, in a new service-based start-up, everyone is involved in all activities and tasks as the company focuses on the development and delivery of services and early market identity. After market acceptance, during the second sequence, hierarchy and decreased involvement coincide with fast-track career opportunities in the rapidly growing service business. In the third sequence, as the resource-mature service business faces a saturated market, it needs to take an organisational approach to employee efficiency and effectiveness. Finally, in the fourth sequence, standardized career tracks and training and hiring are used to support sustained growth and to build a uniform growth culture.

Growth. This theme refers to how the models described the changes in terms of measurable growth indicators and related growth characteristics. The meta-analysis showed that during the first sequence, the new service business moves from challenges to meeting cash demands to a cash flow that breaks even thanks to early customers. During the second sequence, market acceptance leads to fast growth and positive cash flow, which is used to finance rapid growth. In the third sequence, the growth in the cash flow of a resource-mature company starts to decrease in a highly competitive and saturated market. Finally, during the fourth sequence, through diversified growth strategies and a uniform culture, growth momentum is regained and cash flow increases, while new geographic locations and business areas are added to the portfolio of the service company.

The main aim of this meta-analysis was to form a self-evaluation framework for early stage service-based companies. The self-evaluation framework is presented in Table 5:

[Table 5 should be placed here]

Because the framework presented in Table 5 is probabilistic in nature, it does not determine an inevitable linear sequence of stages in organisational development in parallel to biological life cycles. From the probabilistic perspective, a firm may be born in one or more of the stages (e.g., spin-offs), return from one stage to another (e.g., failure of the first business model), skip a stage (e.g., through acquisition), stay in one stage for a long time 
(e.g., stagnation) or go out of business unexpectedly (e.g., collapse of the business model) (see Muhos, 2015).

\section{Discussion}

The purpose of this study was to review the literature on growth configuration, which is often referred to as the stages of growth or the lifecycle of service-based companies. This study explored the characteristics, shared themes and common patterns of previous empirical growth configuration models of service-based businesses. The review provided a synthesis of previous empirical models in the form of a self-evaluation framework.

The configuration perspective offers multiple frameworks for managing growth and supporting service-based companies in their growth paths. The following research questions were posed:

RQ1. What are the basic characteristics of recent empirical studies on the early stages of service-based firms?

RQ2. What are the themes and sequential patterns in the early stages of service-based firms as revealed in the recent empirical literature?

The first research question was answered in section 3 of this paper. First, a preliminary sample of recent empirical models of providing value to service-based companies was selected from the configuration literature. Second, the preliminary sample was divided into two periods for analysis (First period: years 1980-1999, Second period: years 2000-2012). The sample and the two periods are presented in Appendix 1. Third, the characteristics of the selected models were analysed. The condensed results of the analysis are presented in Table 1. The analysis showed the following: 1) the recent studies included more servicebusiness-focus studies than the early studies did; 2) the majority of the empirical surveys were conducted in recent studies; and 3) the recent studies showed more consistency than the early studies did; 4) the recent service-business-focused studies showed remarkable consistency compared to the earlier generic models in both content and the number of stages. Based on the review of preliminary sample, nine recent models with a clear focus on service-based businesses were selected as the final sample used for the in-depth metaanalysis. The final sample of nine studies is presented in Table 2.

The second research question was answered in section 4. First, the key characteristics of the nine selected models were analysed. The results of this analysis are shown in Table 3. The analysis revealed remarkable consistency among these models. Second, the shared themes were identified. The nine shared themes were focus, power, organisational structure, decision-making systems, strategic management, development and delivery of services, marketing, human resources and growth. Third, the shared developmental sequences of the models were identified in each shared theme. The findings showed that the models followed a pattern of four stages. The stages were labelled as follows: 1) Startup - Growth through market exploration and commercialization of service (s); 2) Take-off - Growth through market acceptance; 3) Resource maturity - Growth through profitability and renewal; and 4) Diversification - Growth through diversification. Based on the identified themes and stages, a grid-type self-evaluation framework of the early stages of service-based firms was developed and described in section 6 (see Table 5).

The main aim of this study was to form a framework that could provide accurate support for new service-based companies. Table 6 summarises the four stages in the selfevaluation framework. 
[Table 6 should be placed here]

This study presented a probabilistic framework (see Eggers et al., 1994; Filley \& Aldag, 1980; Garengo \& Bernardi, 2007; Hasenfeld \& Schmid, 1989; Muhos, 2015). Because it is a probabilistic framework, it is not intended to determine inevitable linear sequences of stages in organisational development that parallel biological life cycles.

The stage framework is an effective tool for reflecting on and predicting the challenges encountered during the early development of a company. The framework presented in Table 6 functions as a self-evaluation framework of growth in the early stages of servicebased firms, for which universal growth models provide limited assistance. Focused approaches, such as presented in this study, can lead to the development of better tools to support growth management in service-based firms. The framework provides an in-depth understanding of the early stages of service-based firms useful for public and private intermediary organisations seeking to provide effective support services. By using this framework, such intermediaries can provide accurate support for their customers in the service business sector.

Business growth is a multidimensional and heterogeneous phenomenon. The results of the present meta-analytical study could encourage the academic community to develop context-specific understanding of the early stages of business growth instead of seeking a universal solution. Universal frameworks are simply not adequate. The meta-analysis presented here is a starting point rather than an end. The self-evaluation framework provides a useful reference for the future research. Furthermore, the framework will be tested to provide greater understanding of the early stages by using empirical evidence. By using the self-evaluation framework as a reference, it could be possible to analyse the special characteristics of growth in different sectors of the service industry and in different cultural and geographical contexts.

The study is based on a meta-analytical research strategy, and the self-evaluation framework is based on recent, focused and empirical models of stages of growth. However, this study has several limitations. Because this study is meta-analytical, it does not contain any preliminary or secondary data. The data used in this study were extracted from company-focused configuration studies published since 1980. One challenge in the metaanalysis of the configuration viewpoint is that the original data were not presented clearly in several studies. The data collection was limited to configuration studies published between 1980 and 2012. Although configuration studies were published both earlier and later than the selected timespan, they were not within the focus of this study. Some previous configuration studies may not have been considered in this study, but a reasonable proportion of configuration studies published during the study periods were included in this analysis. To some extent, this study is interpretative, and therefore the possibility of subjective bias must be acknowledged.

\section{References}

Aplin, J. C., \& Cosier, R. A. (1980). Managing creative and maintenance organization. The Business Quaterly, 45(1), 56-64.

Auzair, S. M. (2010). Organisational life cycle stages and management control systems in service organisations. International Journal of Business and Management, 5(11), 5665 . 
Baird, L., \& Meshoulam, I. (1988). Managing two fits of strategic human resource management. The Academy of Management Review, 13(1), 116-128.

Churchill, N. C., \& Lewis, V. L. (1983). The five stages of small business growth. Harvard Business Review, 61(3), 30-50.

Coase, R. H. (1937). The nature of the firm. Economica, 4(16), 386-405.

Cook, T. D., Cooper, H., Cordray, D. S., Hartmann, H., Hedges, L. V., \& Light, R. J. (1992). Meta-analysis for explanation: A casebook Russell Sage Foundation.

Cooper, H., Hedges, L. V., \& Valentine, J. C. (2009). The handbook of research synthesis and meta-analysis Russell Sage Foundation.

Davidsson, P., \& Wiklund, J. (2006). 3. conceptual and empirical challenges in the study of firm growth. In P. Davidsson, Entrepreneurship and the Growth of Firms. Cheltenham: Edvard Elgar Publishing.

Dodge, H. R., Fullerton, S., \& Robbins, J. E. (1994). Stage of the organizational life cycle and competition as mediators of problem perception for small businesses. Strategic Management Journal, 15(2), 121-134.

Dodge, H. R., \& Robbins, J. E. (1992). An empirical investigation of the organizational life cycle model for small business development and survival. Journal of Small Business Management, 30(1), 27-37.

Eggers, J. H., Leahy, K. T., \& Churchill, N. C. (1994). Stages of small business growth revisited: Insights into growth path and leadership/management skills in low- and high-growth companies. Frontiers of Entrepreneurship Research 1994, Proceedings of the Fourteenth Annual Entrepreneurship Research Conference, Babson Park. 131144.

Empson, L. (2012). 15 beyond dichotomies: A multi-stage model of governance in professional service firms. In M. Rechlen, \& A. Werr (Eds.), Handbook of research on entrepreneurship in professional services (1st ed., pp. 274-294). Cheltenham: Edward Elgar Publishing.

Ferreira, J. J. M., Azevedo, S. G., \& Cruz, R. P. (2011). SME growth in the service sector: A taxonomy combining life-cycle and resource-based theories. The Service Industries Journal, 31(2), 251-271.

Filley, A. C., \& Aldag, R. J. (1980). Organizational growth and types: Lessons from small institutions. Research in Organizational Behavior, 2, 279-321.

Flamholtz, E. (1986). How to make the transition from an entrepreneurship to a professionally managed firm (1st ed.). San Fransisco: Jossey-Bass.

Garengo, P., \& Bernardi, G. (2007). Organizational capability in SMEs: Performance measurement as a key system in supporting company development. International Journal of Productivity and Performance Management, 56(5-6), 518-532.

Geroski, P. A. (2002). The growth of firms in theory and in practice. In N. Foss, \& V. Mahnke (Eds.), Competence, governance, and entrepreneurship (2nd ed., pp. 168186). Oxford: Oxford University Press.

Gibrat, R. (1931). Les inégalités économiques (1st ed.). Paris: Recueil Sirey.

Glass, G. V. (1976). Primary, secondary, and meta-analysis of research. Educational Researcher, 5(10), 3-8.

Greiner, L. (1972). Evolution and revolution as organisations grow. Harward Business Review, 50(4), 37-46.

Greiner, L., \& Malernee, J. (2005). Managing growth stages in consulting firms. In L. Greiner, \& F. Poulfelt (Eds.), Management consulting today and tomorrow: Perspectives and advice from 27 leading world experts (1st ed., pp. 456-491) Routledge. 
Guo, C., \& Miller, J. K. (2010). Guanxi dynamics and entrepreneurial firm creation and development in china. Management and Organization Review, 6(2), 267-291.

Hanks, S. H., \& Chandler, G. (1994). Patterns of functional specialization in emerging high tech firms. Journal of Small Business Management, 32(2)

Hanks, S. H., Watson, C. J., Jansen, E., \& Chandler, G. N. (1993). Tightening the life-cycle construct: A taxonomic study of growth stage configurations in high-technology organizations. Entrepreneurship: Theory and Practice, 18(2)

Hannan, M. T., \& Freeman, J. (1977). The population ecology of organizations. The American Journal of Sociology, 82(5), 929-964.

Hasenfeld, Y., \& Schmid, H. (1989). The life cycle of human service organizations: An administrative perspective. Administration in Social Work, 13(3/4), 243-269.

Kazanjian, R. K., \& Drazin, R. (1990). A stage-contingent model of design and growth for technology based new ventures. Journal of Business Venturing, 5(3), 137-150.

Kimberly, J. R. (1980). Initiation, innovation, and institutionalization in the creation process. In J. R. Kimberly, \& R. H. Miles (Eds.), The organizational life cycle: Issues in the creation, transformation, and decline of organizations (1st ed., pp. 18-43). London: Jossey-Bass.

Lester, D. L., Parnell, J. A., \& Menefee, M. L. (2008). Organizational life cycle and performance among SMEs: Generic strategies for high and low performers. International Journal of Commerce and Management, 18(4), 313-330.

Levie, J., \& Lichtenstein, B. B. (2010). A terminal assessment of stages theory: Introducing a dynamic states approach to entrepreneurship. Entrepreneurship Theory and Practice, 34(2), 317-350.

Masurel, E., \& Van Montfort, K. (2006). Life cycle characteristics of small professional service firms*. Journal of Small Business Management, 44(3), 461-473.

McClelland, D. C. (1961). The achieving society (1st ed.). Princeton: Van Nostrand.

Miller, D. (1981). Toward a new contingency approach: The search for organizational gestalts. Journal of Management Studies, 18(1), 1-26.

Miller, D., \& Friesen, P. H. (1984). A longitudinal study of the corporate life cycle. Management Science, 30(10), 1161-1183.

Muhos, M. (2015). Review of business growth models: Methodology and the assumption of determinism. International Journal of Management and Enterprise Development, 14(4), 288-306.

Muhos, M., Kess, P., Phusavat, K., \& Sanpanich, S. (2010). Business growth models: Review of past 60 years. International Journal of Management and Enterprise Development, 8(3), 296-315.

Muhos, M., Kess, P., Rasochova, L., \& Foit, D. (2016). Early stages of technologyintensive companies in california. International Journal of Innovation and Learning, 19(3), 244-271.

Muhos, M., Kess, P., Distanont, A., Phusavat, K., \& Sanpanich, S. (2014). Early stages of technology-intensive companies in thailand and finland. International Journal of Economics and Business Research, 7(2), 177-197.

Muhos, M., Lee, T., Chang, S., \& Kess, P. (2014). Growth strategies in early-stage technology-intensive firms. In F-L T Yu \& H-D Yan. Handbook of East Asian Entrepreneurship, Routledge, (1st ed., pp. 68-80)

Ndonzuau, F. N., Pirnay, F., \& Surlemont, B. (2002). A stage model of academic spin-off creation. Technovation, 22(5), 281-289.

Nelson, R. R., \& Winter, S. G. (1982). An evolutionary theory of economic change (1st ed.). Cambridge: Belknap Press. 
O'Farrell, P. N., \& Hitchens, D. (1988). Alternative theories of small-firm growth: A critical review. Environment and Planning, 20(3), 1365-1383.

Olson, P. D. (1987). Entrepreneurship and management. Journal of Small Business Management, 25(3), 7-13.

Penrose, E. T. (1959). The theory ofthe growth of the firm (1st ed.). New York: JohnWiley\&Sons.

Perry, C. (1982). Stage theories of small business growth. Management Forum, 8(4), 190203.

Phelps, R., Adams, R., \& Bessant, J. (2007). Life cycles of growing organizations: A review with implications for knowledge and learning. International Journal of Management Reviews, 9(1), 1-30.

Quinn, R. E., \& Cameron, K. (1983). Organizational life cycles and shifting criteria of effectiveness: Some preliminary evidence. Management Science, 29(1), 33-51.

Rutherford, M. W., Buller, P. F., \& McMullen, P. R. (2003). Human resource management problems over the life cycle of small to medium-sized firms. Human Resource Management, 42(4), 321-335.

Sandberg, W. R., \& Hofer, C. W. (1982). A strategic management perspective on the determinants of new venture success. In K. H. Vesper (Ed.), Frontiers of entrepreneurship research (1st ed., pp. 204-237). Wellesley: Babson College.

Shim, S., Eastlick, M. A., \& Lotz, S. (2000). Examination of US hispanic-owned, small retail and service businesses: An organizational life cycle approach. Journal of Retailing and Consumer Services, 7(1), 19-32.

Siu, W., \& Kirby, D. A. (1998). Approaches to small firm marketing. European Journal of Marketing, 32(1/2), 40-60.

Stam, E. (2007). Why butterflies don't leave: Locational behavior of entrepreneurial firms. Economic Geography, 83(1), 27.

Stubbart, C. I., \& Smalley, R. D. (1999). The deceptive allure of stage models of strategic processes. Journal of Management Inquiry, 8(3), 273-286.

Teeter, R. A., \& Whelan-Berry, K. S. (2008). My firm versus our firm: The challenge of change in growing the small professional service firm. Journal of Business Inquiry, 32(3), 41-52.

Terpstra, D. E., \& Olson, P. D. (1993). Entrepreneurial start-up and growth: A classification of problems. Entrepreneurship: Theory and Practice, 17(3), 5-20.

Tornatzky, L. G., Eveland, J. D., Boylan, M. G., Hetzner, W. A., Johnson, E. C., Roitman, D., . . Schneider, J. (1983). The process of technological innovation: Reviewing the literature (1st ed.). Washington: National Science Foundation.

Van Tonder, C., \& McMullan, L. (2010). Franchisees, change, and the life cycle. Proceedings of the GBATA 2010 - 12th Annual International Conference, 5 Jul 2010, South Africa, GBATA.

Whetten, D. A. (1987). Organizational growth and decline processes. Annual Review of Sociology, 13(1), 335-358.

Wiklund, J. (1998). Small firm growth and performance: Entrepreneurship and beyond. dissertation. (1st ed.). Jönköping: Jönköping University, Jönköping International Business School.

Williamson, O. E. (1975). Markets and hierarchies: Analysis and antitrust implications: A study in the economics of internal organization (1st ed.). New york: Free Press.

Witmeur, O., \& Fayolle, A. (2011). Developing and testing a typology of growth strategies of entrepreneurial IT service firms. In M. Raposo, D. Smallbone, K. Balaton \& L. Hortoványi (Eds.), Entrepreneurship, growth and economic development (1st ed., pp. 30-68). Cheltenham: Edward Elgar Publishing. 
Appendix 1: The preliminary sample of studies and the two episodes of analysis

\begin{tabular}{|c|c|}
\hline $\begin{array}{l}\text { The 1980s and 1990s } \\
\text { (1980-1999) }\end{array}$ & $\begin{array}{l}\text { The New Millennium } \\
(2000-2014)\end{array}$ \\
\hline 1. $\quad$ Kimberly, 1980; Kimberly, 1979 & 12. Shim et al., 2000 \\
\hline Filley \& Aldag, 1980 & 13. Ndonzuau et al., 2002 \\
\hline Aplin \& Cosier, 1980 & 14. Rutherford et al., 2003 \\
\hline Quinn \& Cameron, 1983 & 15. Greiner \& Malernee, 2005 \\
\hline Flamholtz, 1986 & 16. Masurel \& Van Montfort, 2006 \\
\hline Olson, 1987 & 17. Stam, 2007 \\
\hline Baird \& Meshoulam, 1988 & 18. Lester et al., 2008 \\
\hline Dodge \& Robbins, 1992 & 19. Teeter \& Whelan-Berry, 2008 \\
\hline Terpstra \& Olson, 1993 & 20. Auzair, 2010 \\
\hline 10. Dodge et al., 1994 & 21. Guo \& Miller, 2010 \\
\hline \multirow[t]{4}{*}{ 11. Eggers et al., 1994} & 22. Van Tonder \& McMullan, 2010 \\
\hline & 23. Witmeur \& Fayolle, 2011 \\
\hline & 24. Ferreira et al., 2011 \\
\hline & 25. Empson, 2012 \\
\hline
\end{tabular}

Table 6. Early stages of service-based companies: the self-evaluation framework

\begin{tabular}{|c|c|}
\hline Stage & Stage description/assumption codes \\
\hline Stage 1: Start-up & $\begin{array}{l}(1-\mathrm{A} 1 *) \text { The service-based start-up is focused on the development and delivery } \\
\text { of services and building market identity in order to survive. (1-A2) Decision } \\
\text { making is owner-dependent as owner-manager(s) lead a small group of } \\
\text { employees. (1-A3) The structure is informal, simple and owner-centred. (1-A4) }\end{array}$ \\
\hline $\begin{array}{l}\text { Growth through market } \\
\text { exploration and } \\
\text { commercialization of } \\
\text { service(s) }\end{array}$ & $\begin{array}{l}\text { Formal decision-making systems and procedures are almost non-existent. (1- } \\
\text { A7) New businesses focus on attracting early customers, and (1-A6) the } \\
\text { development and delivery of innovative services are everyone's job. (1-A8) } \\
\text { Everyone is involved in everything in a small start-up. (1-A5) At this point, } \\
\text { owner-manager(s) lack time for strategic planning. (1-A9) In terms of growth, } \\
\text { the company moves from challenges to meet cash demands to cash flow that } \\
\text { breaks even with support from early customers. }\end{array}$ \\
\hline Stage 2: Take-off & $\begin{array}{l}\text { (2-A1) As market acceptance leads service-based business to rapid growth and } \\
\text { constant change, the primary focus is on growth management. (2-A2) The } \\
\text { owner-manager(s) maintain control but delegate responsibilities to a small } \\
\text { management team. (2-A3) The structure of the firm is formalised gradually } \\
\text { through task specialization. (2-A4) The firm moves rapidly from basic decision- } \\
\text { making systems to scalable systems that are compatible with the growing }\end{array}$ \\
\hline $\begin{array}{l}\text { Growth through market } \\
\text { acceptance }\end{array}$ & $\begin{array}{l}\text { business. (2-A6) The firm delivers and scales services efficiently to meet } \\
\text { increasing market demand as (2-A7) the number of sectors, activities and client } \\
\text { types increases rapidly. (2-A8) From an employee perspective, hierarchy and } \\
\text { decreased involvement coincide with fast-track career opportunities. (2-A5) } \\
\text { Strategic planning is focused on maintaining continuous growth. (2-A9) In } \\
\text { terms of growth, market acceptance leads to fast growth and positive cash flow; } \\
\text { cash flow and/or debt is used to finance growth. }\end{array}$ \\
\hline $\begin{array}{l}\text { Stage 3: Resource } \\
\text { maturity }\end{array}$ & $\begin{array}{l}\text { (3-A1) Because of market saturation and increased competition, the focus of a } \\
\text { service-based business shifts to improving profitability and efficiency by } \\
\text { formalising rules, procedures and financial controls. (3-A2) Original owner- } \\
\text { manager(s) and the management team are often supported by professional } \\
\text { executives. (3-A3) A formal structure with defined roles and responsibilities is } \\
\text { introduced. (3-A4) Enterprise strategies, rules and policies become written and }\end{array}$ \\
\hline \multirow{4}{*}{$\begin{array}{c}\text { Growth through } \\
\text { profitability and renewal }\end{array}$} & supported by extensive operational systems. (3-A8) The firm takes an \\
\hline & $\begin{array}{l}\text { organisational approach to employee efficiency and effectiveness. (3-A6) To } \\
\text { avoid stagnation, fresh innovation methods are needed as (3-A7) are new market }\end{array}$ \\
\hline & knowledge and ideas to maintain market position, expand and/or renew. (3-A5) \\
\hline & Strategic management is both formalised and supported by financial resources. \\
\hline
\end{tabular}


(3-A9) The growth of cash flow starts to decrease in a highly competitive and saturated market.

\begin{tabular}{cl}
\hline Stage 4: Diversification & (4-A1) To gain new momentum, the service-based business focuses on new \\
& service generation, business areas and/or locations and on the development of a \\
& uniform business culture. (4-A2) Owner-manager(s) are often supported or \\
& replaced by professional leaders with corporate experience. (4-A3) A \\
& sophisticated organisation structure with formalised functions and processes is \\
Growth through & introduced. (4-A4) Strategies, rules and policies are developed, codified and \\
diversification & communicated by analytical mechanisms. (4-A6) Innovative culture enables \\
& implementing diversified service-market strategies. (4-A7) Simultaneously, a \\
& uniform corporate image is maintained within diverse markets through \\
professional marketing. (4-A8) Standardized career tracks and training/hiring \\
are used to build "the firm approach" and culture. (4-A5) Strategy development \\
and implementation are routine at corporate headquarters. (4-A9) Growth \\
momentum is regained, and cash flow growth accelerates.
\end{tabular}

*The assumptions are coded in the table as 1-A1 -4-A9 (for example 1-A1 equals stage 1, assumption 1) 

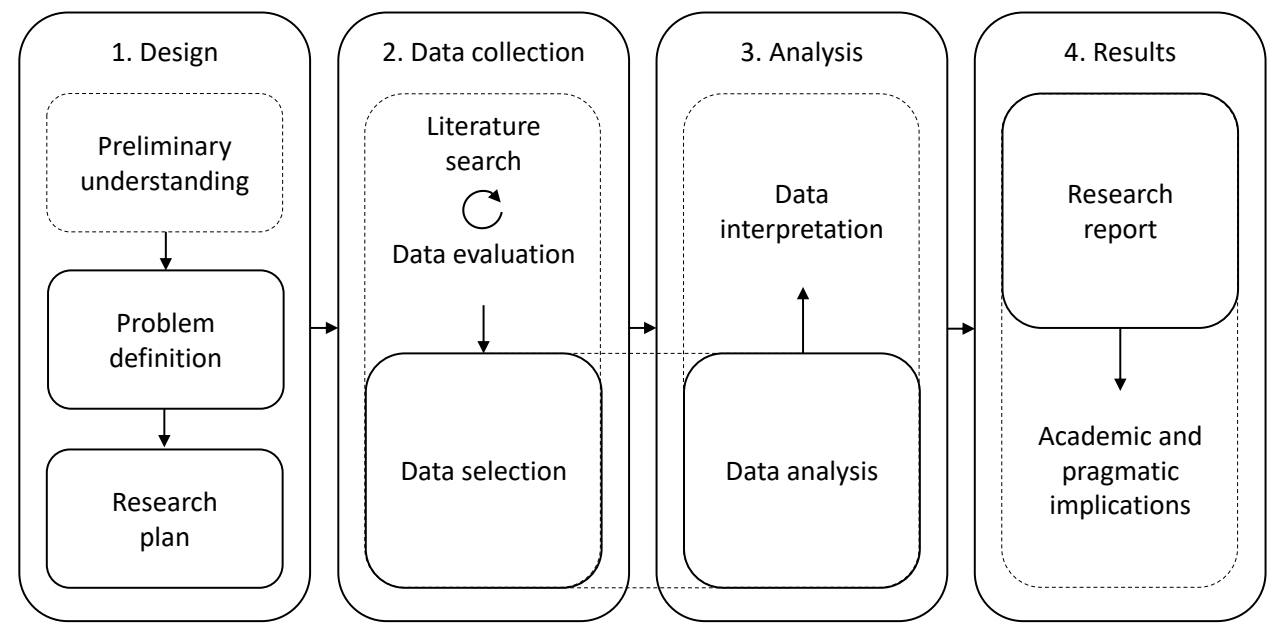

Figure 1. The research process used in this meta-analysis

Table 1. The preliminary sample of empirically based growth configuration studies focused on service-based businesses

\begin{tabular}{|c|c|c|c|c|c|}
\hline $\begin{array}{l}\text { Number, Identity of the author(s) } \\
\text { and study, Year published }\end{array}$ & $\begin{array}{l}\text { Peer } \\
\text { Review }\end{array}$ & $\begin{array}{l}\text { Focus } \\
\text { Business* }\end{array}$ & Stages & $\begin{array}{l}\text { Research } \\
\text { Strategy }\end{array}$ & $\begin{array}{l}\text { Size of } \\
\text { Sample }\end{array}$ \\
\hline 1. Kimberly, 1980 & yes & service & 3 & $\begin{array}{l}\text { action } \\
\text { research }\end{array}$ & 1 \\
\hline 2. Filley and Aldag, 1980 & yes & generic & 3 & survey & 272 \\
\hline 3. Aplin and Cosier, 1980 & yes & generic & 3 & case study & 2 \\
\hline 4. Quinn and Cameron, 1983 & yes & generic & 4 & case study & 1 \\
\hline 5. Flamholtz, 1986 & no & generic & 4 & case study & 8 \\
\hline 6. Olson, 1987 & yes & generic & 2 & case study & 2 \\
\hline 7. Baird and Meshoulam, 1988 & yes & generic & 5 & case study & 24 \\
\hline 8. Dodge and Robbins, 1992 & yes & generic & 4 & case study & 362 \\
\hline 9. Terpstra and Olson, 1993 & yes & generic & 2 & survey & 115 \\
\hline 10. Dodge et al., 1994 & yes & generic & 4 & case study & 645 \\
\hline 11. Eggers et al. 1994 & yes & generic & 6 & survey & 237 \\
\hline 12. Shim, et al., 2000 & yes & service & 5 & survey & 416 \\
\hline 13. Ndonzuau et al., 2002 & yes & generic & 4 & case study & 15 \\
\hline 14. Rutherford et al., 2003 & yes & generic & 4 & survey & $\begin{array}{l}2,90 \\
3\end{array}$ \\
\hline 15. Greiner and Malernee, 2005 & no & service & 4 & case study & 200 \\
\hline $\begin{array}{l}\text { 16. Masurel and Van Montfort, } \\
2006\end{array}$ & yes & service & 4 & survey & 279 \\
\hline 17. Stam, 2007 & yes & generic & 5 & $\begin{array}{l}\text { case study, } \\
\text { survey }\end{array}$ & 174 \\
\hline $\begin{array}{l}\text { 18. Lester, Parnell, and } \\
\text { Menefee, } 2008\end{array}$ & yes & generic & 5 & survey & 94 \\
\hline $\begin{array}{l}\text { 19. Teeter and Whelan-Berry, } \\
2008\end{array}$ & yes & service & 4 & case study & 1 \\
\hline 20. Auzair, 2010 & yes & service & 3 & survey & 149 \\
\hline
\end{tabular}


21. Guo and Miller, 2010 yes generic $3 \quad$ case study 11

22. Van Tonder and McMullan, yes $\quad$ service $\quad 5 \quad$ survey 21

23. Witmeur and Fayolle, 2011 yes $\quad$ service $\quad 3-4 \quad$ case study 4

$\begin{array}{llllll}\text { 24. Ferreira et al., } 2011 \text { yes } & \text { service } & 5 & \text { survey }\end{array}$

$\begin{array}{llllll}25 . & \text { Empson, } 2012 \text { yes } & \text { service } & 5 & \text { case study } & 13\end{array}$

*Generic models seek to provide added value for both product and service businesses

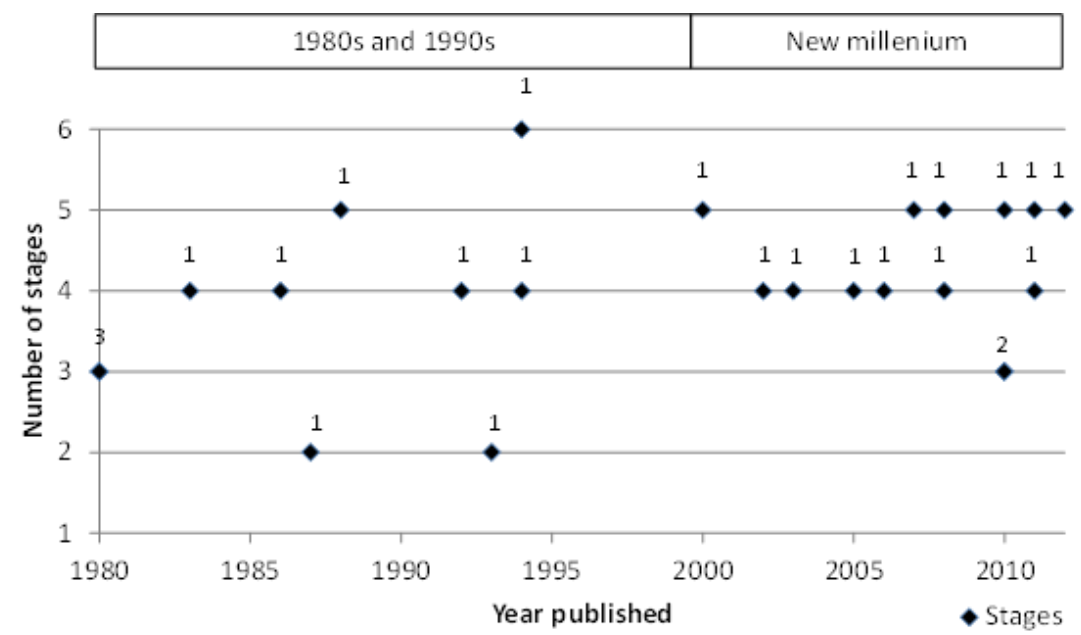

$1,2, \ldots, n=$ number of models published proposing the same number of stages

Figure 2. The two episodes of the analysis and the number of stages across the sample

Table 2. The sample of recent empirical studies included in the meta-analysis

\begin{tabular}{|c|c|c|c|c|c|}
\hline Author(s), Year & $\begin{array}{l}\text { Peer } \\
\text { Review }\end{array}$ & $\begin{array}{l}\text { Focus } \\
\text { Business }\end{array}$ & Stages & $\begin{array}{l}\text { Research } \\
\text { Strategy }\end{array}$ & $\begin{array}{l}\text { Size of } \\
\text { Sample }\end{array}$ \\
\hline 1. Shim et al., 2000 & yes & service & 5 & survey & 416 \\
\hline $\begin{array}{l}\text { 2. Greiner and Malernee, } \\
2005\end{array}$ & no & service & 4 & case study & 200 \\
\hline $\begin{array}{l}\text { 3. Masurel and Van } \\
\text { Montfort, } 2006\end{array}$ & yes & service & 4 & survey & 279 \\
\hline $\begin{array}{l}\text { 4. Teeter and Whelan-Berry, } \\
2008\end{array}$ & yes & service & 4 & case study & 1 \\
\hline 5. Auzair, 2010 & yes & service & 3 & survey & 149 \\
\hline $\begin{array}{l}\text { 6. Van Tonder and } \\
\text { McMullan, } 2010\end{array}$ & yes & service & 5 & survey & 21 \\
\hline $\begin{array}{l}\text { 7. Witmeur and Fayolle, } \\
2011\end{array}$ & yes & service & $3-4$ & case study & 4 \\
\hline 8. Ferreira et al., 2011 & yes & service & 5 & survey & 23 \\
\hline Empson, 2012 & yes & service & 5 & case study & 13 \\
\hline
\end{tabular}

Table 3. Comparison of the key characteristics of the models 


\begin{tabular}{|c|c|c|c|}
\hline Author(s), Year & Focal Firms & Key Perspective(s) & Stages \\
\hline Shim et al., 2000 & $\begin{array}{l}\text { Service firms: } \\
\text { small US Hispanic- } \\
\text { owned retail and } \\
\text { service businesses }\end{array}$ & $\begin{array}{l}\text { management style, } \\
\text { structural complexity, } \\
\text { operational systems, } \\
\text { strategic planning \& } \\
\text { owner involvement }\end{array}$ & $\begin{array}{l}\text { (1) existence } \\
\text { (2) survival } \\
\text { (3) success } \\
\text { (4) take-off } \\
\text { (5) resource maturity }\end{array}$ \\
\hline $\begin{array}{l}\text { Greiner and } \\
\text { Malernee, } 2005\end{array}$ & $\begin{array}{l}\text { Professional service } \\
\text { firms: consulting } \\
\text { firms }\end{array}$ & $\begin{array}{l}\text { strategy, } \\
\text { structure, } \\
\text { systems and rewards, } \\
\text { management style, } \\
\text { decision process, } \\
\text { culture \& } \\
\text { sources of conflict }\end{array}$ & $\begin{array}{l}\text { (1) exploring } \\
\text { (2) focusing } \\
\text { (3) diversifying } \\
\text { (4) institutionalizing }\end{array}$ \\
\hline $\begin{array}{l}\text { Masurel and Van } \\
\text { Montfort, } 2006\end{array}$ & $\begin{array}{l}\text { Service firms: } \\
\text { Dutch architectural } \\
\text { firms }\end{array}$ & $\begin{array}{l}\text { sales diversification, } \\
\text { labour differentiation } \\
\& \text { labour productivity }\end{array}$ & $\begin{array}{l}\text { (1) starting } \\
\text { (2) growth } \\
\text { (3) maturity } \\
\text { (4) decline } \\
\end{array}$ \\
\hline $\begin{array}{l}\text { Teeter and Whelan- } \\
\text { Berry, } 2008\end{array}$ & $\begin{array}{l}\text { Professional service } \\
\text { firms: } \\
\text { US-based } \\
\text { accounting firm }\end{array}$ & $\begin{array}{l}\text { organisational change, } \\
\text { change management, \& } \\
\text { cultural change }\end{array}$ & $\begin{array}{l}\text { (1) start stage } \\
\text { (2) growth stage } \\
\text { (3) mature stage } \\
\text { (4) decline stage }\end{array}$ \\
\hline Auzair, 2010 & $\begin{array}{l}\text { Service firms: } \\
\text { Australian retail and } \\
\text { wholesale, health } \\
\text { services, education, } \\
\text { hospitality, etc. } \\
\text { firms }\end{array}$ & $\begin{array}{l}\text { management control } \\
\text { systems }\end{array}$ & $\begin{array}{l}\text { (1) formation } \\
\text { (2) growth } \\
\text { (3) maturity }\end{array}$ \\
\hline $\begin{array}{l}\text { Van Tonder and } \\
\text { McMullan, } 2010\end{array}$ & $\begin{array}{l}\text { Service firms: } \\
\text { South African } \\
\text { franchisees }\end{array}$ & organisational change & $\begin{array}{l}\text { (1) gestation } \\
\text { (2) entrepreneurial } \\
\text { (3) methods and } \\
\text { systems } \\
\text { (4) } \\
\text { maturation/decline } \\
\text { (5) renewal }\end{array}$ \\
\hline $\begin{array}{l}\text { Witmeur and } \\
\text { Fayolle, } 2011\end{array}$ & $\begin{array}{l}\text { Service firms: IT } \\
\text { service firms in } \\
\text { Belgium }\end{array}$ & $\begin{array}{l}\text { entrepreneurial team, } \\
\text { activities, } \\
\text { resources, } \\
\text { structure, } \\
\text { environment \& } \\
\text { growth strategy }\end{array}$ & $\begin{array}{l}\text { (1) start-up } \\
\text { (2) early growth } \\
\text { (3) continued growth } \\
\text { or } \\
\text { (1) seed } \\
\text { (2) start-up } \\
\text { (3) early growth } \\
\text { (4) continued growth }\end{array}$ \\
\hline Ferreira et al., 2011 & $\begin{array}{l}\text { Service firms: } \\
\text { hotel and restaurant } \\
\text { service industries of } \\
\text { Cape Verde }\end{array}$ & $\begin{array}{l}\text { context, } \\
\text { structure } \\
\text { strategy, } \\
\text { decision-making style } \\
\text { \& level of resources }\end{array}$ & $\begin{array}{l}\text { (1) birth } \\
\text { (2) expansion } \\
\text { (3) maturity } \\
\text { (4) diversification } \\
\text { (5) decline }\end{array}$ \\
\hline Empson, 2012 & $\begin{array}{l}\text { Professional service } \\
\text { firms: management } \\
\text { consulting, law, } \\
\text { accounting and } \\
\text { actuarial firms in } \\
\text { UK }\end{array}$ & $\begin{array}{l}\text { governance \& } \\
\text { complexity }\end{array}$ & $\begin{array}{l}\text { (1) founder focused } \\
\text { (2) collegial } \\
\text { (3) committee } \\
\text { (4) delegated } \\
\text { (5) corporate }\end{array}$ \\
\hline
\end{tabular}


Table 4. Relationship of the original stages and the synthesis

\begin{tabular}{|c|c|c|c|c|c|c|c|}
\hline Author(s)/Year & \multicolumn{6}{|c|}{ Stages } & $*$ \\
\hline 1. Shim et al., 2000 & 1 & 1 & 2 & 2 & 3 & & \\
\hline 2. Greiner and Malernee, 2005 & \multicolumn{2}{|c|}{1} & \multicolumn{2}{|c|}{2} & 3 & 4 & \\
\hline 3. Masurel and Van Montfort, 2006 & \multicolumn{2}{|c|}{1} & \multicolumn{2}{|c|}{2} & 3 & & d \\
\hline 4. Teeter and Whelan-Berry, 2008 & \multicolumn{2}{|c|}{1} & \multicolumn{2}{|c|}{2} & 3 & & $\mathrm{~d}$ \\
\hline 5. Auzair, 2010 & \multicolumn{2}{|c|}{1} & \multicolumn{2}{|c|}{2} & 3 & & \\
\hline 6. Van Tonder and McMullan, 2010 & 1 & 1 & \multicolumn{2}{|c|}{2} & 3 & 4 & \\
\hline 7. Witmeur and Fayolle, 2011 (part a) & \multicolumn{2}{|c|}{1} & \multicolumn{2}{|c|}{2} & 3 & & \\
\hline$($ part b) & 1 & 1 & \multicolumn{2}{|c|}{2} & 3 & & \\
\hline 8. Ferreira et al., 2011 & \multicolumn{2}{|c|}{1} & \multicolumn{2}{|c|}{2} & 3 & 4 & d \\
\hline 9. Empson, 2012 & \multicolumn{2}{|c|}{1} & 2 & 2 & 3 & 4 & \\
\hline Sequencing for synthesis & & & \multicolumn{2}{|c|}{2} & 3 & 4 & \\
\hline
\end{tabular}

Notes: A single number in the table $=$ a single stage in the original model

$1,2,3, \ldots \mathrm{n}=$ a related stage number in the synthetic self-evaluation framework

$* \mathrm{~d}=$ "decline" proposed as stage by three models was not included in the synthesis

Table 5. Early stages of service-based companies - the self-evaluation framework

\begin{tabular}{|c|c|c|c|c|}
\hline & Stage 1: Start-up & Stage 2: Take-off & $\begin{array}{l}\text { Stage 3: Resource } \\
\text { maturity }\end{array}$ & $\begin{array}{l}\text { Stage 4: } \\
\text { Diversification }\end{array}$ \\
\hline Focus & $\begin{array}{l}\text { A1.1* The focus is } \\
\text { on development and } \\
\text { delivery of services } \\
\text { and building market } \\
\text { identity in order to } \\
\text { survive. }\end{array}$ & $\begin{array}{l}\text { A2.1 The focus is on } \\
\text { growth management } \\
\text { as market acceptance } \\
\text { leads to rapid growth } \\
\text { and constant change. }\end{array}$ & $\begin{array}{l}\text { A3.1 The focus is } \\
\text { on efficiency by } \\
\text { formalising rules, } \\
\text { procedures and } \\
\text { financial controls in } \\
\text { a saturated market. }\end{array}$ & $\begin{array}{l}\text { A } 4.1 \text { The focus is } \\
\text { on new service } \\
\text { generation, } \\
\text { business areas } \\
\text { and/or locations } \\
\text { and on a uniform } \\
\text { business culture. }\end{array}$ \\
\hline Power & $\begin{array}{l}\text { A1.2 Decision } \\
\text { making is owner- } \\
\text { dependent as owner- } \\
\text { manager(s) lead } \\
\text { small group of } \\
\text { employees. }\end{array}$ & $\begin{array}{l}\text { A2.2. Owner- } \\
\text { manager(s) maintain } \\
\text { control but delegate } \\
\text { responsibilities to a } \\
\text { small management } \\
\text { team. }\end{array}$ & $\begin{array}{l}\text { A3.2 Original } \\
\text { owner-manager(s) } \\
\text { and the } \\
\text { management team } \\
\text { are supported by } \\
\text { professional } \\
\text { executives. }\end{array}$ & $\begin{array}{l}\text { A4.2 Owner- } \\
\text { manager(s) are } \\
\text { supported or } \\
\text { replaced by } \\
\text { professional leaders } \\
\text { with corporate } \\
\text { experience. }\end{array}$ \\
\hline Structure & $\begin{array}{l}\text { A1.3 The structure } \\
\text { is simple, informal } \\
\text { and owner-centred. }\end{array}$ & $\begin{array}{l}\text { A2.3 The structure is } \\
\text { formalised gradually } \\
\text { through task } \\
\text { specialization. }\end{array}$ & $\begin{array}{l}\text { A3.3 A formal } \\
\text { structure with } \\
\text { defined roles and } \\
\text { responsibilities is } \\
\text { introduced. }\end{array}$ & $\begin{array}{l}\text { A4.3 A } \\
\text { sophisticated } \\
\text { structure with } \\
\text { formalised } \\
\text { functions and } \\
\text { processes is } \\
\text { introduced. }\end{array}$ \\
\hline $\begin{array}{l}\text { Decision- } \\
\text { making } \\
\text { systems }\end{array}$ & $\begin{array}{l}\text { A1.4 Formal } \\
\text { decision-making } \\
\text { systems and } \\
\text { procedures are } \\
\text { almost non-existent. }\end{array}$ & $\begin{array}{l}\text { A } 2.4 \text { The firm moves } \\
\text { rapidly from basic } \\
\text { decision-making } \\
\text { systems to scalable } \\
\text { systems compatible } \\
\text { with growing } \\
\text { business. }\end{array}$ & $\begin{array}{l}\text { A3.4 Enterprise } \\
\text { strategies, rules and } \\
\text { policies become } \\
\text { written and } \\
\text { supported by } \\
\text { extensive } \\
\text { operational systems. }\end{array}$ & $\begin{array}{l}\text { A4.4 Codified } \\
\text { strategies, rules and } \\
\text { policies are } \\
\text { communicated by } \\
\text { sophisticated } \\
\text { analytical } \\
\text { mechanisms. }\end{array}$ \\
\hline $\begin{array}{l}\text { Strategic } \\
\text { management }\end{array}$ & $\begin{array}{l}\text { A1.5 Owner- } \\
\text { manager(s) lack } \\
\text { time for strategic } \\
\text { planning. }\end{array}$ & $\begin{array}{l}\text { A2.5 Strategic } \\
\text { planning is focused } \\
\text { on maintaining } \\
\text { continuous growth. }\end{array}$ & $\begin{array}{l}\text { A3.5 Strategic } \\
\text { management is both } \\
\text { formalised and } \\
\text { supported by } \\
\text { financial resources. }\end{array}$ & $\begin{array}{l}\text { A4.5 Strategy } \\
\text { implementation is } \\
\text { routine at corporate } \\
\text { headquarters. }\end{array}$ \\
\hline $\begin{array}{l}\text { Service } \\
\text { development } \\
\text { and delivery }\end{array}$ & $\begin{array}{l}\text { A1.6 Development } \\
\text { and delivery of }\end{array}$ & $\begin{array}{l}\text { A2.6 The firm } \\
\text { delivers and scales } \\
\text { services efficiently to }\end{array}$ & $\begin{array}{l}\text { A3.6 Fresh and } \\
\text { continuous } \\
\text { innovation methods }\end{array}$ & $\begin{array}{l}\text { A4.6 Innovative } \\
\text { culture enables } \\
\text { implementing }\end{array}$ \\
\hline
\end{tabular}




\begin{tabular}{|c|c|c|c|c|}
\hline & $\begin{array}{l}\text { innovative services } \\
\text { are everyone's job. }\end{array}$ & $\begin{array}{l}\text { meet increasing } \\
\text { market demand. }\end{array}$ & $\begin{array}{l}\text { are implemented to } \\
\text { avoid stagnation. }\end{array}$ & $\begin{array}{l}\text { diversified service- } \\
\text { market strategies. }\end{array}$ \\
\hline Marketing & $\begin{array}{l}\text { A1.7 New } \\
\text { businesses focus on } \\
\text { attracting early } \\
\text { customers. }\end{array}$ & $\begin{array}{l}\text { A2.7 Sectors, } \\
\text { activities and client } \\
\text { types increase } \\
\text { rapidly. }\end{array}$ & $\begin{array}{l}\text { A3.7 New ideas are } \\
\text { needed to maintain } \\
\text { market position, } \\
\text { expand and/or } \\
\text { renew. }\end{array}$ & $\begin{array}{l}\text { A4.7 A uniform } \\
\text { image is spread to } \\
\text { diverse markets } \\
\text { through } \\
\text { sophisticated } \\
\text { marketing. }\end{array}$ \\
\hline $\begin{array}{l}\text { Human } \\
\text { resources }\end{array}$ & $\begin{array}{l}\text { A1.8 Everyone is } \\
\text { involved in } \\
\text { everything in a } \\
\text { small start-up. }\end{array}$ & $\begin{array}{l}\text { A2.8 Hierarchy and } \\
\text { decreased } \\
\text { involvement coincide } \\
\text { with fast-track career } \\
\text { opportunities. }\end{array}$ & $\begin{array}{l}\text { A3.8 The firm takes } \\
\text { an organisational } \\
\text { approach to } \\
\text { employee efficiency } \\
\text { and effectiveness. }\end{array}$ & $\begin{array}{l}\text { A4.8 Standardized } \\
\text { career tracks and } \\
\text { training/hiring are } \\
\text { used to build a } \\
\text { uniform culture. }\end{array}$ \\
\hline Growth & $\begin{array}{l}\text { A1.9 Moves from } \\
\text { challenges to meet } \\
\text { cash demands to a } \\
\text { cash flow that } \\
\text { breaks even thanks } \\
\text { to early customers. }\end{array}$ & $\begin{array}{l}\text { A2.9 Market } \\
\text { acceptance leads to } \\
\text { fast growth and } \\
\text { positive cash flow; } \\
\text { cash flow and/or debt } \\
\text { is used to finance } \\
\text { growth. }\end{array}$ & $\begin{array}{l}\text { A3.9 The growth of } \\
\text { cash flow decreases } \\
\text { in a highly } \\
\text { competitive and } \\
\text { saturated market. }\end{array}$ & $\begin{array}{l}\text { A4.9 Growth } \\
\text { momentum is } \\
\text { regained, and cash } \\
\text { flow increases. }\end{array}$ \\
\hline
\end{tabular}

